\title{
Post-Neo-Kantianism and/or Transcendental Idealism ${ }^{*}$
}

\author{
VLADIMIR BELOV, ANASTASIA LEBEDEVA \\ Faculty of Humanities and Social Sciences, RUDN University, 6 Miklukho-Maklaya Street, 117198 Moscow, Russia \\ Email: belov-vn@rudn.ru; lebedeva-av@rudn.ru
}

\begin{abstract}
This article explores the development of continental philosophy of critical transcendentalism after World War II. The intention to interpret Kant's transcendentalism corresponds both to the demand to establish feasibility and necessity of conclusive rational grounds for the validity of our cognition and to the need to legitimise the claim of philosophy to be irrefutable in the justification of its principles. While resisting attempts to find the basis for the determination of reason outside the reason itself, post-neo-Kantian continental transcendentalism also rejects the voluntarist scheme of the constructive relation of reason to the external environment. This approach implies the emergence of philosophical projects that offer alternatives to the postmodernist relativisation of philosophical results and to the skepticism that emerges within that framework.
\end{abstract}

Keywords: Neo-Kantianism, post-neo-Kantianism, transcendental idealism, philosophical system, metaphysics, ontology

\section{INTRODUCTION}

The article intends to examine and resolve two major hypotheses. First, the paper illustrates that the tradition of transcendental idealism continues through the framework of the Neo-Kantian movement. The nature of this continuation can be compared to the double-faced Janus. On the one hand, it is focused on the past, on the identification of additional similarities and differences within Neo-Kantianism, especially within its two main schools and their representatives. Furthermore, the comparative analysis of European philosophical movements of the beginning of the 20th century proves to be an important aspect of contemporary studies of Neo-Kantianism, since it points out a significant impact that Neo-Kantian methodology has had on the formation and development of the most prominent philosophical schools and movements of that time. On the other hand, the continuation outlined above is focused on the future, since Neo-Kantian ideas are considered relevant concepts that can provide a philosophical basis for the analysis of contemporary social processes of science, individual, society and culture.

Second, the paper argues that post-neo-Kantianism is undergoing such major transformations that some scholars consider it incomparable with Neo-Kantianism and instead focus only on the development of transcendental philosophy in general rather than on the development of Neo-Kantianism.

This article has been supported by the RUDN University Strategic Academic Leadership Program. 
Current interest in Neo-Kantianism and post-neo-Kantianism can be determined by several factors. For one thing, it is worth noting that Neo-Kantianism asserts the importance of reflecting upon the method of philosophising in the context of modern research in natural and human studies. Critical idealism of Neo-Kantianism transcends both the philosophical system that relies on objective identity and the philosophical system that builds upon subjective identity. Thus, critical idealism of Neo-Kantianism, and especially its Marburg school, represents idealism that rejects concentration on both the object and the subject as the result of reasoning. Critical idealism of Neo-Kantianism argues that it is neither an object nor a subject that shape the nature of reasoning, but rather the methodological principle of pure reason itself underlies both the object and the subject of that very reasoning.

Furthermore, contemporary historical and philosophical studies of Neo-Kantianism emphasise the undeniable influence that this school of thought had on prominent 20th-century scholars, such as Edmund Husserl, Martin Heidegger, Gottlob Frege and Rudolf Carnap (De Warren, Staiti 2015; Makkreel, Luft 2010; Luft 2015). The following two trends are emphasised: first, the trend towards comparing the achievements and potential of Neo-Kantian methodology with the methodology of analytic philosophy (Edel 2010); second, the trend towards combining the methodology of Neo-Kantian transcendental philosophy with phenomenology (Luft 2018).

Another important point to consider is that Neo-Kantianism asserts itself as a philosophy of culture by applying the Kantian thesis on the critique of reason to the critique of culture. The Neo-Kantian perception of culture as a cohesive phenomenon built on dialogic principles remains relevant in the current discource on culture (Luft 2015).

Lastly, it should be noted that social, political, humanistic, religious and philosophical ideas of Neo-Kantianism remain relevant. This school of thought acts as an alternative to postmodernism in its justification of humanistic ideas. By offering radically new principles and approaches that are consonant with postmodern ideas, Neo-Kantian critical idealism in its ethical aspect of reasoning illustrates the potential of such reasoning, which is critical of reality and open to diverse variations of its development. Neo-Kantianism justifies ethical socialism, while examining the problems of social upbringing and social order (Holzhey 1994). Neo-Kantianism also aims to validate interfaith and interreligious dialogue on rational and ethical bases (Lohmann 1995).

\section{PATTERNS OF DEVELOPMENT AND TRANSFORMATION OF NEO-KANTIANISM}

There are at least three interrelated dimensions of the development and transformation of Neo-Kantianism - historical, universally philosophical and systemic. The first, historical dimension is primarily concerned with external matters, such as historical, religious and ideological aspects. The second, universally philosophical dimension is to be regarded as general tendencies in the development of global philosophy. And the third, systemic dimension is linked to internal processes in the development of Neo-Kantianism.

How is the historical dimension to be interpreted in this context? First, it is important to note that the concept of Neo-Kantianism was unjustly neglected for a rather considerable part of the 20th century. This marginalization of Neo-Kantianism among the European philosophers began shortly after World War I and was considerably accelerated over the course of World War II and thereafter. It was primarily prompted by the growing antisemitism in Germany during the 1920s and 1930s, seeing how some of the most prominent Neo-Kantians, such as Hermann Cohen, Ernst Cassirer, Emil Lask and Richard Hönigswald, were Jewish. Furthermore, many 
followers of the Neo-Kantian schools had to emigrate from Germany, and their geographic remoteness from one another posed a significant obstacle to their cooperation.

Universally philosophical dimension, in turn, is rooted in the cultural and intellectual crisis in Europe after World War I. Neo-Kantianism with its classical rationalist approach lost its rationale in the trenches of the First World War and suffered the ultimate defeat in the Cassirer-Heidegger debate in March 1929. From the perspective of the interwar generation, philosophy was supposed to address the 'things-in-themselves' and the 'lifeworld', to liberate itself from the interference of the special sciences and the limitations imposed by philosophical systems.

Nevertheless, seeing how the context around philosophy has been changing significantly since the 1980s, a steadily increasing interest in Neo-Kantianism can be observed. Not only does this interest focus on the historical and philosophical aspect of the emergence and development of Neo-Kantianism that, according to many historians of philosophy, held a leading position in global philosophy from the late 19th century to the first quarter of the 20th century, but it also points out those intensions of Neo-Kantianism that are still relevant today and that are being developed by modern philosophers. The search for such a worldview, which would establish reasonable principles of human existence by pushing boundaries of reason in the new world that has been affected by the tragic events of the 20th century, becomes even more relevant in the context of multiplicity of social, political and cultural processes within European countries and Russia. Neo-Kantianism has been steadily gaining prominence as the ideology that closely conforms to such requirements.

Still, the third dimension of the development of Neo-Kantianism appears to be of most importance. While it is indisputably associated with the first two dimensions, it is also significant on its own. Relevance of Neo-Kantianism cannot be discussed without mentioning transformation and development of this school of thought. Relevant issues that are addressed in the philosophical systems of Hermann Cohen, Heinrich Rickert and other representatives of classic Neo-Kantian schools cannot be perceived merely on the basis of their fundamentality. The objection might be raised that there are Kant studies and Kantianism that focus on Kant's transcendental philosophy and remain relevant for more than two centuries. However, Neo-Kantians themselves in a sense contrasted their return to Kant with the reasoning of both Kant specialists and Kantians whose attention to Kant's works has existed long before the emergence of Neo-Kantianism. In the paradigm of Kant specialists and Kantians, any change in this reception depends on something strictly Kantian or closely related to Kant (Hinske 2015). In contrast, Neo-Kantians considered it impossible to understand Kant without building on his philosophical vision that does not necessarily have an intrinsic value but rather corresponds to the historical time period, development of science and civilisation, the very nature of human creativity. Combination of these factors can preserve and reveal the full potential of Kant's transcendental thought only through their continuous modernisation.

Such return to Kant requires systematic development and leads to at least three interrelated consequences for Neo-Kantians themselves - ambiguity in defining their philosophical position as New-Kantian, an apparent evolution of this position within Neo-Kantian schools, and, finally, obligation inherent in this position for such a return to Neo-Kantianism that would lead to post-Neo-Kantianism. Otherwise, it was feared that historical limitations of the existence of Neo-Kantianism and its failure to be a defined path towards the development of the Kantian philosophical tradition or even failure to have any systematic development of Kantian transcendentalism altogether will be declared. 
Interconnectedness of these implications means that the difficulty in defining the philosophical position of the followers of Marburg and Baden schools as Neo-Kantian is directly dependent on the evident evolution of the attitude of the main representatives of Neo-Kantian schools, which, in turn, inevitably includes the prospect of transitioning to the next stage of the development of Neo-Kantianism.

When it comes to the late works of Hermann Cohen (with his focus on the individuality through Judaism and his interpretation of the problem of correlation, the problem of dialogue, the problem of individual religious experience, the problem of translating the language of religion into the language of philosophy, etc.) (Poma, Belov 2021) or the late works of Paul Natorp (with his attention to everyday life and to the irrational), there is still the same challenge of translating an irrational nature of life into a comprehensible philosophical language. And while Cohen relies on religious discourse, Natorp uses the language of poetry, hence his impact on Cassirer's 'Philosophy of Symbolic Forms' and his interest in the works of Fyodor Dostoevsky (Belov 2003; Belov 2018; Belov 2020). Heterology in the late work of Heinrich Rickert, 'a representative of the southwestern school of Neo-Kantianism, became the doctrine that led the way not only for that school of thought, but also for the entire post-war transcendental philosophy that focused on subjectivity' (Krijnen 2020).

\section{DISTINCTIVE FEATURES OF POST-NEO-KANTIAN TRANSCENDENTAL PHILOSOPHY}

Several key features of modern post-neo-Kantianism are worth emphasising:

1. Renewed interest in Hegel's philosophy.

Classic Neo-Kantianism continues to contrast traditional Kantian concepts with Fichte and Hegel's approaches. Highlighting the differences between Kant's philosophy and Hegel's idealism, Kantian philosophy is presented as 'a system which does not claim absoluteness of spirit that is identical with being (objective idealism), but which remains linked to emotional experiences through the "critical limit"; thus it is the kind of transcendental idealism that allows Kant's philosophy to assume leadership over science' (Wein 2018).

At the same time, classic Neo-Kantianism intends to build upon Kant and, therefore, embrace his critique and accept other scenarios for the development of Kantian ideas. That is precisely the reason why classic Neo-Kantianism moves away from criticising Hegel towards a more mindful approach of his ideas. This modification cannot be described as some type of evolution from the early to late Neo-Kantianism; rather, this process is inherent in Neo-Kantianism, since Neo-Kantianism claims not only to justify philosophy, but also to identify science as critique of culture. Hence, the trend towards looking for positive aspects in the areas that are relevant to intellectual culture appears as logical strengthening of the movement's original positions rather than deviation from its original intentions.

An extremely illustrative example is the so-called 'Hegel Renaissance' when students and followers of the prominent representatives of Marburg and Baden schools of Neo-Kantianism followed the advice of their venerable teachers and began to approach the Hegel's system of philosophy less critically, in hopes of tailoring his historical and dialectical methods as well as his speculative logic to the Kant's system of critical idealism. The pinnacle of that period in Neo-Kantianism was the two-volume work 'Von Kant bis Hegel' (1921-1924) written by Baden Neo-Kantian scholar Richard Kroner, one of the founders of the Logos multinational journal.

2. Restored interest in the system within philosophy.

It is no secret that since the late 19th century systemic structures in philosophy have been under increasing criticism from a number of philosophical movements. Such systems were 
considered stagnant; they were regarded as products of something that has sunk into inauthenticity or into 'Dasein', as vestiges of German philosophy. These attitudes were amplified by critical theories in society and subsequently by postmodernism, since the critique of rationality and the rejection of system are interconnected. Striving to justify the claim of reason to the reliable and definitive knowledge in attaining the truth, post-neo-Kantianism also strives for the systemic nature of such justification. However, the return of post-neo-Kantian philosophers to systemic structures does take into account the criticism voiced against the system. The nature of the system the way it is understood in classic German idealism is being redefined towards a more comprehensive emphasis on the role of the subject and the infinity of experience.

In particular, Christian Krijnen, while emphasising the importance of the systemic thought of post-neo-Kantian philosophers, such as Hans Wagner and Werner Flach, remarks, 'In spite of any deficit of rationality and any tendency to dissolve systemic philosophy into philosophical historiography or to reduce it to linguistic and philosophical explanation of single problems or naturalization of meaning, Wagner and Flach have demonstrated that the concept of philosophy as fundamental science can be developed and popularized even today' (Krijnen 2009).

3. Reliance on the methodological framework (logicism) in striving to complete the Kantian project of metaphysics as science.

The methodological framework (logicism) of post-neo-Kantian philosophical concepts is evident in their search for ultimate justification in the so-called facilitation ('Vermittlung') and in their utilisation of the Cohenian concept of correlation and the Neo-Kantian principle of mediation. Post-neo-Kantian message strives to overcome the Neo-Kantian dualism of the ultimate foundation of science and to validate 'pure transcendentalism' by explaining the phenomenon of a priori and revealing the mediating character of such concepts as 'subjectivity', while focusing on the statement itself and making the very foundation heterologous. In their perception, it is not about the concepts of either being or mind, but rather about the concepts of both being and mind.

4. Radical anti-ontology.

It has already been stated that the transcendental philosophy of post-neo-Kantianism seeks to develop and even finalise the Kantian notion of scientific metaphysics. Post-neo-Kantian philosophers are confident that it could represent not the metaphysics of being (ontology), but the metaphysics of our comprehension of being. Post-neo-Kantian views differ from those of Neo-Kantians in their more apparent realism in terms of both the objective being and the empirical subject. They are certain that Heidegger's fundamental ontology or Hartmann's new ontology, which define our cognitive style through our being, have nothing in common with Kant's idea of transcendentalism.

\section{CONCLUDING REMARKS}

It is appropriate to highlight Heinrich Rickert's reflections on the death of the follower of the realist movement in Neo-Kantianism Alois Riehl, which happened in 1924, shortly after the death of another prominent Neo-Kantian Paul Natorp. Rickert emphasised that Neo-Kantianism had fulfilled its historical mission, and therefore, anything that followed it would no longer be considered Neo-Kantianism. German philosopher wrote, 'Otto Liebmann, Friedrich Albert Lange, but especially Hermann Cohen, Wilhelm Windelband and Paul Natorp... are justly referred to as Neo-Kantians, seeing how they were directing scientific philosophy back towards Kant, while also significantly moving it forward. This corresponded to the state of 
affairs of their time. Kant was forgotten; his views were no longer understood. In this respect, the ideas prevalent at that time came from the same line of thought that had been overcome by Kant more than a hundred years earlier. Therefore, the future belonged to Neo-Kantians... One should add that Riehl was the last one of this group. He outlived all the other prominent Neo-Kantians, although he was not the youngest of them; thus Neo-Kantianism as a historical phenomenon came to an end with his death. Nowadays, there is not a single significant scholar who befits Neo-Kantianism, and it cannot be any other way. Neo-Kantianism, as it is perceived here, has accomplished its crucial task - fundamental concepts of Kant's works... have shaped themselves through the writings of Neo-Kantians, which will help anyone who's capable of any philosophical thinking to understand these concepts' (Rickert 1924).

German philosopher Hans-Ludwig Ollig argued against such role of Neo-Kantianism and, consequently, against improbability of its further development. In his article 'Neo-Kantianism, Ollig discussed the new phase of Neo-Kantian tradition in the writings of the scholars he considered Neo-Neo-Kantians, such as Rudolf Zocher (1887-1976), Wolfgang Cramer (1901-1974) and Hans Wagner (1917-2000) (Ollig 1979).

Another prominent modern German philosopher Werner Flach explains the desire of some scholars (including Ollig) to classify philosophers of the post-war generation, such as Zocher, Cramer and Wagner, as 'Neo-Neo-Kantians', attributing it to the fact that these authors continued the tradition of perceiving philosophy as the study of validity ('Geltung'), which to some extent corresponded to Neo-Kantians, who 'considered any areas that imply self-discovery to be an integral part of philosophy'. However, Flack agrees with the 'correct perspective' that does not detect any notion of 'Neo-Neo-Kantianism' in the works of these authors (Flach 2012).

Two extreme attitudes towards assessing the development of post-neo-Kantian philosophy should also be mentioned. One of such attitudes was explained by Italian researcher of Neo-Kantianism Pierfrancesco Fiorato in one of his 2011 interviews, 'To state a very broad theme here, increased attention to Neo-Kantianism might be explained by the desire to rectify a very one-sided and stereotypical image of contemporary rationality that has been proliferating through the discussion of postmodernism. The point is not to nurture nostalgia for traditional forms of philosophical thought, which can hardly be justified in light of the profound changes currently taking place in all forms of knowledge and thought. Nevertheless, it is this kind of "idealist" approach, which on the surface may seem detached from the requirements of today's world, that reveals several potentially fruitful features. Neo-Kantianism is precisely the movement that identifies elements of reason due to its radically deconstructed perception of ideas, which manifests itself as a logical viewpoint that challenges generally accepted indisputable facts and creates new correlations. According to the transcendental a priori concept, reason constitutes a code that is to be absolutely assumed yet cannot be applied, since its application will inevitably lead to its destruction and redefinition. This perception of reason strikes me as capable of providing us with valuable information even today. I believe it should still be called "transcendental idealism" or "Neo-Kantianism" (Fiorato 2011).

The second attitude is shared by Polish researchers Andrzej J. Noras and his student Alicja Pietras. They argue that the entire post-neo-Kantian tradition has evolved towards a greater recognition of the necessity to focus primarily on ontological issues. Consequently, they claim that such philosophers as Nicolai Hartmann and Martin Heidegger can be rightfully considered post-neo-Kantians (Noras 2005, 2020; Pietras 2008).

We will not focus here on this radical Polish variant of enlisting outstanding thinkers, creators of the so-called ontological turn in the philosophy of the 20th century, into the ranks 
of the post-neo-Kantians, but let us turn briefly to the argumentation of the most consistent, thorough and balanced researcher of the post-neo-Kantian tradition, Professor Kurt Walter Zeidler of the University of Vienna. He himself, in his conception of transcendental logic, as the final logical justification, can be attributed to this tradition.

K. W. Zeidler conducted a fundamental analysis of the phenomenon of post-neo-Kantianism in his monograph 'Critical Dialectics and Transcendental Ontology. The Legacy of Neo-Kantianism and Post-Neo-Kantian Systematics', where he also discussed in detail the works of such thinkers as Richard Hönigswald, Hans Krämer, Bruno Bauch, Hans Wagner, Robert Reininger and Erich Heintel.

Zeidler identified two features that distinguish post-neo-Kantianism from Neo-Kantianism - first, post-neo-Kantian return to Hegel, which he calls the 'Hegel Renaissance', its development of 'critical dialectics' as opposed to the Neo-Kantian 'construction of the ideal subject' and its greater attention to the 'tension between the existential subject and the area of values'; second, the post-neo-Kantian development of transcendental ontology as an alternative to Hartmann's new ontology and Heidegger's existential ontology. Both of these features of post-neo-Kantianism focus on systemic structures, within which the representatives of this school of thought, while confronting the dominant philosophical trends of the interwar and postwar periods, such as new ontology, philosophy of life and existential philosophy, strive to convey the claim for idea and existence in a dialectical manner. The Viennese professor gives examples of such attempts to overcome the Neo-Kantian constructivism of the ideal subject by mentioning Erich Heintel's specification of transcendence or Hans Wagner's philosophy of concrete subjectivity (Zeidler 1995).

Nevertheless, for all the apparent differences in the aforementioned approaches, the two approaches that recognise the existence of the post-neo-Kantian period in the development of transcendental philosophy are to be considered the most well-reasoned and justified. Moreover, while there are differences in the definition of this subsequent to the Neo-Kantianism period, both these approaches - the one that refers to this period as post- or neo-Neo-Kantian and the one that refuses to give it this name - essentially emphasise the same features. A specific nature of these approaches lies in certain nuances. Proponents of the first approach are more insistent in emphasising their connection with Neo-Kantianism and its uncovered possibilities. Proponents of the second approach identify the same connection in a broader context of transcendental philosophy as a whole, thus Neo-Kantian objectives are not considered determinative within this approach.

Received 21 November 2021 Accepted 18 January 2022

\section{References}

1. Belov, V. N. 2003. 'Ernst Cassirer. The Philosophy of Symbolic Forms', Problems of Philosophy 12: 177-182.

2. Belov, V. N. 2018. 'Autonomy of Reason and the Religion of Revelation in the Philosophy of the Religion of Hermann Cohen', Philosophy of Religion: Analytic Researches 2(2): 51-64.

3. Belov, V. N. 2020. 'Cohen and Natorp's Philosophy of Religion: The Argument about the Boundary of Reason', Kantian Journal 39(3): 54-71.

4. De Warren, N.; Staiti, A. 2015. New Approaches to Neo-Kantianism. Cambridge: Cambridge University Press.

5. Edel, G. 2010. Hypothesis versus Linguistic Turn: Zur Kritik der sprachanalytischen Philosophie. Waldkirch: Edition Gorz.

6. Fiorato, P. 2011. Antwort auf die Fragen von Ana Thereza de Miranda Cordeiro Dürmaier der Federal University of Paraíba über das erneute Interesse für Neukantianismus. Brazil: Federal University of Paraíba.

7. Flach, W. 2012. 'Zur Neubewertung des Neukantianismus', in Marburg versus Südwestdeutschland. Philosophische Differenzen zwischen den beiden Hauptschulen des Neukantianismus, eds. Ch. Krijnen and A. J. Noras. Würzburg: Königshausen und Neumann, 9-40. 
8. Hinske, N. 2015. 'Kantianism, Kant Philology and Kant Scholarship', in History of Philosophy Yearbook, ed. N. V. Motroshilova. Moscow: Akvilo Publishers, 154-173.

9. Holzhey, H. 1994. Ethischer Sozialismus: zur Politischen Philosophie des Neukantianismus. Frankfurt am Main: Suhrkamp.

10. Krijnen, Ch. 2009. 'Philosophie als System: Hans Wagner und Werner Flach', Information Philosophie 4: 27-33.

11. Krijnen, Ch. 2020. 'Beginning and Origin. A New Perspective on Rickert's Heterology and Hegel's Logic', in Hegel's Legacy in the History of Philosophy and Culture: To the 250th Anniversary of the Philosopher, eds. A. N. Muravev and A. A. Ivanenko. Saint Petersburg: Saint Petersburg State University Press, 49-77.

12. Lohmann, J. 1995. Karl Barth und Neukantianismus: die Rezeption des Neukantianismus im 'Römerbrief' und ihre Bedeutung für die weitere Ausarbeitung der Theologie Karl Barths. Berlin: De Gruyter.

13. Luft, S. 2015. The Space of Culture: Towards a Neo-Kantian Philosophy of Culture (Cohen, Natorp, and Cassirer). Oxford: Oxford University Press.

14. Luft, S. 2015. The Neo-Kantian Reader. New York: Routledge.

15. Luft, S. 2018. Kant, Neo-Kantianism, and Phenomenology. Oxford: Oxford University Press.

16. Makkreel, R.; Luft, S. 2010. Neo-Kantianism in Contemporary Philosophy. Bloomington: Indiana University Press.

17. Noras, A. J. 2005. Kant a Neokantyzm Badeński i Marburski. 2nd ed. Katowice: Wydawnictwo Uniwersytetu Śląskiego.

18. Noras, A. J. 2020. 'Post-Neo-Kantianism. What is this?', RUDN Journal of Philosophy 24(1): 89-98.

19. Ollig, H. L. 1979. Der Neukantianismus. Stuttgart: Metzler.

20. Pietras, A. 2008. Postneokantowskie Projekty Filozofii. Nicolai Hartmann i Martin Heidegger. PhD Dissertation. Katowice: Uniwersytet Śląski.

21. Poma, A.; Belov, V. N. 2021. 'Is Hermann Cohen a Classical Philosopher?', RUDN Journal of Philosophy 25(3): 371-377.

22. Rickert, H. 1924. 'Alois Riel', Logos 13: 162-185.

23. Wein, W. 2018. Visual Turn. Platon - Descartes - Kant - Cassirer. Die Wende von Empirismus, Analytischer Philosophie und Naturalismus zu einem modernen, rationalistischen Neukantianismus. 2nd ed. Würzburg: Königshausen und Neumann.

24. Zeidler, K. W. 1995. Kritische Dialektik und Transzendentalontologie. Der Ausgang des Neukantianismus und die post-neukantianische Systematik. R. Hönigswalds, W. Cramers, B. Bauchs, H. Wagners, R. Reiningers und E. Heintels. Bonn: Bouvier.

VLADIMIR BELOV, ANASTASIA LEBEDEVA

\section{Postneokantizmas ir / arba transcendentalusis idealizmas}

Santrauka

Straipsnyje nagrinejjama kontinentinès kritinio transcendentalizmo filosofijos raida po Antrojo pasaulinio karo. Ketinimas interpretuoti Kanto transcendentalizmą atitinka tiek reikalavimą nustatyti galutinių racionalių pagrindų tinkamumą mūsų validžiam pažinimui, tiek poreikị ịteisinti filosofijos pretenziją būti nepaneigiamam grindžiant savo principus. Priešindamasis bandymams rasti pagrindą proto sprendiniams už paties proto ribų, postneokantinis kontinentinis transcendentalizmas taip pat atmeta voliuntaristinę proto konstruktyvaus santykio su išorine aplinka schemą. Šis požiūris suponuoja filosofinių projektų, siūlančių alternatyvas postmodernistiniam filosofinių rezultatų sureliatyvinimui ir drauge atsirandančiam skepticizmui, atsiradimą.

Raktažodžiai: neokantizmas, postneokantizmas, transcendentalusis idealizmas, filosofinè sistema, metafizika, ontologija 